\title{
Endoscopic necrosectomy of walled-off pancreatic necrosis by large-bore percutaneus metal stent: a new opportunity?
}

\section{(ㄷ)(우우}

Authors

Andrea Tringali ${ }^{1}$, Salvatore F. Vadalà di Prampero ${ }^{2}$, Vincenzo Bove ${ }^{1}$, Vincenzo Perri ${ }^{1}$, Antonio La Greca ${ }^{3}$, Gilda Pepe ${ }^{3}$, Valerio Cozza ${ }^{3}$, Guido Costamagna ${ }^{4}$

Institutions

1 Digestive Endoscopy Unit, Catholic University, Rome, Italy

2 Department of Gastroenterology and GI Endoscopy, University Hospital of Udine, Italy

3 Emergency Surgery Unit, Catholic University, Rome, Italy

4 Chair of Digestive Endoscopy, IHU-USIAS, University of Strasbourg, Strasbourg, France

submitted 11.9.2017

accepted after revision $\quad 1.12 .2017$

\section{Bibliography}

DOI https://doi.org/10.1055/s-0043-125313 |

Endoscopy International Open 2018; 06: E274-E278

(c) Georg Thieme Verlag KG Stuttgart · New York

ISSN 2364-3722
Corresponding author

Andrea Tringali, MD, PhD, Digestive Endoscopy Unit,

Catholic University, Largo Agostino Gemelli 8, 00168 Rome, Italy

Fax: +3906 30157220

andrea.tringali@unicatt.it

\section{ABSTRACT}

Background and study aims Endoscopic drainage of walled-off pancreatic necrosis (WOPN) is feasible when contact with the gastric or duodenal wall is present; when WOPN cannot be accessed endoscopically, a percutaneous approach can be considered. Percutaneous use of esophageal self-expandable metal stents (SEMS) to establish access to a WOPN cavity was evaluated.

\section{Introduction}

Development of well-circumscribed areas of necrosis is a complication of acute pancreatitis, occurring in approximately $5 \%$ to $10 \%$ of patients [1]; moreover, after 4 weeks of maturation, an enhancing wall of reactive tissue may surround the necrotic area, resulting in a "walled-off pancreatic necrosis" (WOPN), as described in the 2012 revised Atlanta classification [1].

The optimal interventional modality for treatment of WOPN remains controversial [2]. The PANTER study demonstrated that a "step-up" approach, starting with computed tomography-guided percutaneous drain placement was superior to up-front open surgical necrosectomy, thus supporting the value of a minimally invasive approach for this condition [3].

Direct percutaneous/endoscopic necrosectomy was first described in 2000 [4]. Three recent series [5-7] as well as case reports [ $8-11$ ] described the use of a percutaneous access to enter the WOPN for debridement and washout using flexible endoscopy. This allows the patient to avoid major surgery and could be used for various types of intra-abdominal fluid collec- tions, regardless of anatomic location, provided that it can be first accessed by interventional radiology techniques.

This technique requires multiple dilations of the percutaneous tract in order to be able to insert scopes into the necrotic cavity.

Navarrete [12] proposed percutaneous insertion of esophageal self-expandable metal stents (SEMS) with the aim of making access to the necrotic cavity faster and easier.

Three cases of percutaneous/endoscopic necrosectomy through a large-bore esophageal SEMS are described here.

\section{Case reports}

Between June 2016 and January 2017, 3 patients (3 M, mean age 45 years, range 39-64) with symptomatic WOPN not accessible by EUS through the stomach or duodenum or contraindication to transmural drainage, were treated by endoscopic necrosectomy through a percutaneous large-bore esophageal SEMS. The diameter of the WOPN was $15 \mathrm{~cm}$ (range 7-20) on average. The mean interval between diagnosis of WOPN and initial treatment was 8 weeks (range 4-10). Written informed 
- Table 1 Patient demographics and clinical data.

\begin{tabular}{|c|c|c|c|c|c|c|c|c|c|c|c|}
\hline $\begin{array}{l}\text { Pa- } \\
\text { tient } \\
\text { no. }\end{array}$ & $\begin{array}{l}\text { Age, } \\
\text { years }\end{array}$ & Sex & $\begin{array}{l}\text { Pancrea- } \\
\text { titis } \\
\text { etiology }\end{array}$ & $\begin{array}{l}\text { WOPN } \\
\text { diameter, } \\
\text { cm }\end{array}$ & $\begin{array}{l}\text { WOPN } \\
\text { distri- } \\
\text { bution }\end{array}$ & $\begin{array}{l}\text { Gastric } \\
\text { or duo- } \\
\text { denal } \\
\text { contact }\end{array}$ & $\begin{array}{l}\text { Contrain- } \\
\text { dication to } \\
\text { transmur- } \\
\text { al endo- } \\
\text { scopic } \\
\text { drainage }\end{array}$ & $\begin{array}{l}\text { Infec- } \\
\text { tion }\end{array}$ & Symptoms & $\begin{array}{l}\text { WOPN- } \\
\text { induced } \\
\text { complica- } \\
\text { tions }\end{array}$ & Comorbidity \\
\hline 1 & 64 & M & Post-ERCP & 7 & $\begin{array}{l}\text { Sp, Alp, } \\
\text { Pob, } \\
\text { Gsl, Sh }\end{array}$ & Yes & $\begin{array}{l}\text { Cochlear } \\
\text { implanta- } \\
\text { tion } \\
\text { (monopo- } \\
\text { lar current } \\
\text { contraindi- } \\
\text { cated) }\end{array}$ & Yes & $\begin{array}{l}\text { Pain, } \\
\text { fever }\end{array}$ & $\begin{array}{l}\text { Portal vein } \\
\text { system com- } \\
\text { pression }\end{array}$ & $\begin{array}{l}\text { Benign prostatic } \\
\text { hypertrophy } \\
\text { Diabetes } \\
\text { Hypertension }\end{array}$ \\
\hline 2 & 39 & M & Alcoholic & 18 & $\begin{array}{l}\text { Alp, } \\
\text { Pob }\end{array}$ & No & $\begin{array}{l}\text { No contact } \\
\text { with gastric } \\
\text { or duode- } \\
\text { nal wall }\end{array}$ & Yes & $\begin{array}{l}\text { Pain, } \\
\text { fever }\end{array}$ & - & - \\
\hline 3 & 45 & M & $\begin{array}{l}\text { Post-kid- } \\
\text { ney trans- } \\
\text { plantation }\end{array}$ & 20 & $\begin{array}{l}\text { Alp, } \\
\text { Em, Rh }\end{array}$ & Yes & $\begin{array}{l}\text { Referred } \\
\text { after per- } \\
\text { cutaneous } \\
\text { drainage } \\
\text { placement }\end{array}$ & Yes & $\begin{array}{l}\text { Pain, } \\
\text { fever, dys- } \\
\text { pnea }\end{array}$ & $\begin{array}{l}\text { Pancreatico- } \\
\text { duodenal } \\
\text { vessels com- } \\
\text { pression } \\
\text { Cranial sple- } \\
\text { nic disloca- } \\
\text { tion }\end{array}$ & $\begin{array}{l}\text { Colonic diverti- } \\
\text { culosis, Diabetes, } \\
\text { Hypertension, } \\
\text { Polycystic kidney } \\
\text { disease }\end{array}$ \\
\hline
\end{tabular}

ERCP, endoscopic retrograde cholangiopancreatography ; WOPN, walled-off necrosis; Alp, anterior left pararenal; Emg, epimesogastric region; Gsl, gastrosplenic ligament; Pob, posterior wall of omental bursa; Rh, right hypochondrium; Sh, splenic hilum;

consent for off-label percutaneous insertion of the esophageal SEMS was obtained from all patients, who were also informed about the alternative treatments. Patient characteristics are summarized in $>$ Table 1.

\section{Percutaneous/endoscopic technique}

Following a step-up approach $[3,13]$ all patients received a 10 20 french percutaneous drain; in that frame a fluid sample was collected and sent for amylase level, cytology and microbiology. After a mean time of 6 days (range $4-10$ ) the patients still experienced fever and drainage of the percutaneous tube was almost absent. For that reason, under deep sedation with propofol, the percutaneous drain was removed, leaving a 0.035 inch stiff guidewire (Terumo Medical Corp., Tokyo, Japan) on site, under fluoroscopic control. Subsequently a 12-mm balIoon dilatation (CRE PRO Wireguided 10-12 mm, Boston Scientific Corp, Marlborough, Ma) of the cutaneous tract was performed to pass the stent delivery catheter and to allow opening of the stent. An 18-to 20-mm wide esophageal partially-covered SEMS (Evolution Esophageal controlled-release stent, Cook Group Inc., Bloomington, In; Ultraflex Esophageal NG Stent System, Boston Scientific Corp, Marlborough, Ma) was deployed transcutaneously at the site of necrosis ( $>$ Fig. 1a) ( $\triangleright$ Video 1$)$; SEMS length $(8-15 \mathrm{~cm}$ ) was chosen according to the depth/location of the WOPN.

A standard $8.8-\mathrm{mm}$ diameter or $12.9-\mathrm{mm}$ diameter operative gastroscope (Olympus, Tokyo, Japan) was introduced through the SEMS into the necrotic cavity ( $\triangleright$ Fig.1b). The
WOPN was visualized and irrigated with sterile saline and $10 \%$ $\mathrm{H}_{2} \mathrm{O}_{2}$; necrotic debris were removed using blunt removal, washout and solid debris were cleaned with Dormia baskets. Large necrotic pieces were sequentially removed over repeated procedures.

To provide continuous flushing between necrosectomies, a 7 Fr single-pigtail naso-biliary catheter (ENBD-6, Cook Group Inc., Bloomington, In) was placed through the percutaneous esophageal SEMS to the deepest site of the WOPN. The SEMS and the single pigtail drainage were secured to the skin with silk suture.

Once endoscopic debridement was satisfactory ( $>$ Fig. 1c) and CT scan reported more than $75 \%$ reduction of the collection, SEMS was removed without the need for sedation and replaced by a 30 french surgical drain by the endoscopist, under fluoroscopic control in the endoscopic retrograde cholangiopancreatography room. Patients were discharged with the drain in place, which was progressively retrieved during subsequent outpatient visit, until complete removal, once cross-sectional imaging confirmed resolution of the collection ( $>$ Fig. 1d). Monthly office visits were scheduled for the first 3 months after drainage removal to assess possible signs or symptoms of collection recurrence. 


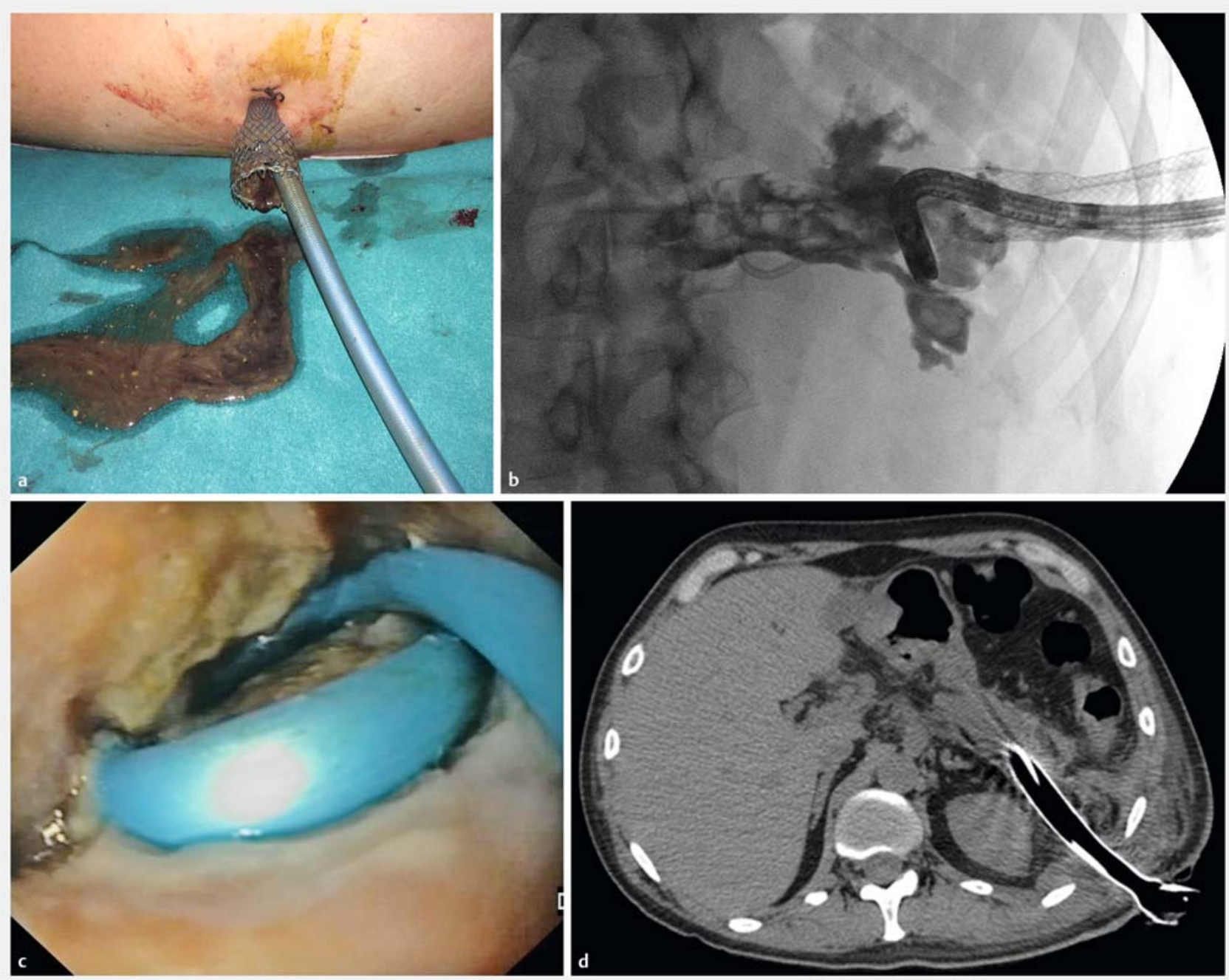

- Fig. 1 Transcutaneous SEMS insertion a and introduction of the endoscope into the necrotic cavity $\mathbf{b}$ final endoscopic $\mathbf{c}$ and CT scan $\mathbf{d}$ result after debridement.

\section{Results}

WOPN resolution by percutaneous necrosectomy through SEMS was achieved in all the patients on CT-scan imaging. An average of 3 endoscopic sessions (range $2-4$ ) was necessary during the entire treatment period. SEMS were easily removed after an average of 12.7 days (range $10-15$ ). The 30 Fr catheter drain was completely removed after an average of 35 days (range 28-42). No procedure-related adverse events were observed.

One of the three patients complained of fever 3 months later. CT scan showed recurrence of a $3 \times 10 \mathrm{~cm}$ fluid collection that was successfully retreated by insertion of a $16 \mathrm{Fr}$ percutaneous drain. No further recurrences were reported.

After a mean follow-up of 181 days (range 150 -239) from the surgical drain removal and treatment of the recurrent collection, all patients are asymptomatic. Therapeutic data and outcomes are summarized in $\mathbf{D}$ Table 2 .

\section{Discussion}

Nowadays several endoscopic modalities have been developed to improve the step-up approach and avoid surgical necrosectomy $[3,14,15]$.

Direct percutaneous endoscopic necrosectomy has shown promising results, even if the literature is still limited [5-7]. In this small series the effectiveness and safety of a novel percutaneous/endoscopic approach to the treatment of infected WOPN without a contact with the stomach or duodenum or contraindication to transmural drainage, was evaluated.

In 2011, a single case report in the literature by Navarrete et al. [12] reported use of percutaneous esophageal SEMS insertion to treat WOPN. Other investigators [5-7] used a percutaneous/endoscopic approach with catheter introduction into the skin to access the collection and perform a wide opening access by balloon dilation to endoscopically debride the WOPN; this approach required repeated dilatation of the cutaneous tract which carries some risk of bleeding [12] and more 
$\checkmark$ Table2 Details of treatment of WOPN drainage with esophageal percutaneous SEMS.

\begin{tabular}{|c|c|c|c|c|c|c|c|c|c|c|}
\hline \multirow[b]{2}{*}{$\begin{array}{l}\text { Pa- } \\
\text { tient } \\
\text { no. }\end{array}$} & \multirow[b]{2}{*}{$\begin{array}{l}\text { Time from } \\
\text { pancreati- } \\
\text { tis onset } \\
\text { to WOPN } \\
\text { treatment, } \\
\text { weeks }\end{array}$} & \multicolumn{2}{|c|}{ Percutaneous drain } & \multicolumn{4}{|c|}{ Percutaneous esophageal SEMS details } & \multirow[b]{2}{*}{$\begin{array}{l}\text { Hospitaliza- } \\
\text { tion from } \\
\text { SEMS place- } \\
\text { ment } \\
\text { (days) }\end{array}$} & \multirow[b]{2}{*}{$\begin{array}{l}30 \mathrm{Fr} \text { drainage } \\
\text { removal after } \\
\text { days }\end{array}$} & \multirow[b]{2}{*}{$\begin{array}{l}\text { Follow-up } \\
\text { from the surgi- } \\
\text { cal drain re- } \\
\text { moval } \\
\text { (days) }\end{array}$} \\
\hline & & $\begin{array}{l}\text { Diameter } \\
\text { (french) }\end{array}$ & $\begin{array}{l}\text { Site of } \\
\text { insertion }\end{array}$ & Type & $\begin{array}{l}\text { Body di- } \\
\text { ameter } \\
\text { (Flared } \\
\text { end di- } \\
\text { ameter) } \\
\text { mm }\end{array}$ & $\begin{array}{l}\text { Length } \\
(\mathrm{cm})\end{array}$ & $\begin{array}{l}\text { Stenting } \\
\text { period } \\
\text { (days) }\end{array}$ & & & \\
\hline 1 & 10 & 16 & $\begin{array}{l}\text { Posterior } \\
\text { (left flank) }\end{array}$ & $\begin{array}{l}\text { Ultraflex } \\
\text { (Boston } \\
\text { Scientific) }\end{array}$ & $18(20)$ & 15 & 15 & 17 & $\begin{array}{l}35 \\
\left(1^{\text {st }} \text { treatment }\right)\end{array}$ & $\begin{array}{l}86 \\
\text { (collection } \\
\text { recurrence) }{ }^{1}\end{array}$ \\
\hline 2 & 4 & 20 & $\begin{array}{l}\text { Posterior } \\
\text { (left flank) }\end{array}$ & $\begin{array}{l}\text { Evolution } \\
\text { (Cook } \\
\text { Endoscopy) }\end{array}$ & $20(25)$ & 15 & 13 & 15 & 42 & $\begin{array}{l}239 \\
\text { (asymptomatic) }\end{array}$ \\
\hline 3 & 10 & 10 & $\begin{array}{l}\text { Anterior } \\
\text { (epigastric) }\end{array}$ & $\begin{array}{l}\text { Evolution } \\
\text { (Cook } \\
\text { Endoscopy) }\end{array}$ & $20(25)$ & 8 & 10 & 21 & 28 & $\begin{array}{l}154 \\
\text { (asymptomatic) }\end{array}$ \\
\hline
\end{tabular}

WOPN, walled-off pancreatic necrosis; SEMS, self-expandable metal stent

${ }^{1}$ Recurrent collection was successfully retreated by 16 Fr percutaneous drainage; patient is asymptomatic more than 3 months after from removal of the drainage.

debridement endoscopic sessions [5,6] than our technique. Furthermore SEMS placement provides wide access without needing repeated dilatations. The catheter inside the esophageal stent allows continuous lavages, facilitating collection healing. Another key factor of our technique is insertion of a large surgical drain once the SEMS was removed, which can prevent a percutaneous fistula.

Short-term resolution of the collection was obtained in all cases, with a recurrence in the first one.

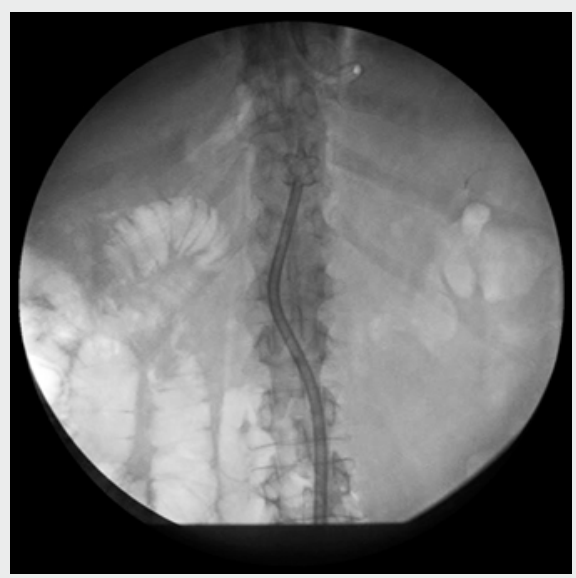

$\triangle$ Video 1 A partially covered, 20-mm esophageal self-expandable metal stent (SEMS) is inserted through the skin into a walled-off pancreatic necrosis. Drainage of the necrotic debris is obtained and the endoscope is advanced into the percutaneous SEMS to perform necrosectomy.
Percutaneous SEMS insertion can become part of the armamentarium of the step-up approach to WOPN, but indications need to be defined considering the following points.

First, percutaneous access along a large-bore esophageal SEMS allows for a wide opening access that also permits a stable position for endoscopic intervention with standard or even therapeutic endoscopes. Second, the percutaneous approach can be used for any intraabdominal fluid collection fit for interventional radiology techniques, such as the pararenal cyst debridement and washout, and omental necrosis debridement included in this series. Third, collections can be drained in the most declivous side which guarantees much better empting in comparison to a transgastric approach, even when it would be feasible. Fourth, a large drainage catheter left in situ after endoscopic sessions and slowly withdrawn can prevent development of a pancreatico-cutaneous fistula, which is a wellknown potential $A E$ of percutaneous drainage of pancreatic fluid collections [7]. Finally, direct percutaneous endoscopic necrosectomy through a SEMS can be performed with standard or therapeutic endoscopes under conscious sedation without the need for general anesthesia, which often is required for prolonged per-oral endoscopies.

There are some limitations to our small consecutive series, mainly absence of a control group and short-term follow-up. Furthermore, this complex procedure can only be performed in a tertiary care center with expert interventional endoscopists, radiological facilities and appropriate surgical availability.

\section{Conclusion}

Despite the limitations of our study, our experience can expand the available armamentarium for treatment of pancreatitis and its complications. Wide percutaneous access to WOPN with 
SEMS is a safe and effective intervention for intraabdominal and retroperitoneal fluid collections and necrosis in appropriately selected patients.

\section{Competing interests}

Dr. Costamagna received grant/research support from Olympus. He is a member on advisory board committees or review panels for Boston Scientific and Cook Endoscopy.

\section{References}

[1] Banks PA, Bollen TL, Dervenis C et al. Classification of acute pancreatitis-2012: revision of the Atlanta classification and definitions by international consensus. Gut 2013; 62: $102-111$

[2] Tenner S, Baillie J, DeWitt J et al. American college of gastroenterology guideline: management of acute pancreatitis. Am J Gastroenterol 2013; 108: $1400-1415$

[3] van Santvoort HC, Besselink MG, Bakker O] et al. A step-up approach or open necrosectomy for necrotizing pancreatitis. N Engl ] Med 2010; 362: $1491-1502$

[4] Carter CR, McKay C], Imrie CW. Percutaneous necrosectomy and sinus tract endoscopy in the management of infected pancreatic necrosis: an initial experience. Ann Surg 2000; 232: 175-180

[5] Dhingra R, Srivastava S, Behra $S$ et al. Single or multiport percutaneous endoscopic necrosectomy performed with the patient under conscious sedation is a safe and effective treatment for infected pancreatic necrosis (with video). Gastrointest Endosc 2015; 81: 351 - 359

[6] Mui LM, Wong SK, Ng EK et al. Combined sinus tract endoscopy and endoscopic retrograde cholangiopancreatography in management of pancreatic necrosis and abscess. Surg Endosc 2005; 19: 393 - 397
7] Mathers B, Moyer M, Mathew A et al. Percutaneous debridement and washout of walled-off abdominal abscess and necrosis using flexible endoscopy: a large single-center experience. Endosc Int Open 2016; 04: E102-E106

[8] Cerecedo-Rodriguez J, Hernandez-Trejo A, Alanis-Monroy E et al. Percutaneous endoscopic pancreatic necrosectomy. Gastrointest Endosc 2014; 80: $165-166$

[9] Inoue T, Ichikawa H, Okumura F et al. Local administration of amphotericin B and percutaneous endoscopic necrosectomy for refractory fungal-infected walled-off necrosis: a case report and literature review. Medicine (Baltimore) 2015; 94: e558

[10] Kumbhari V, Storm AC, Tieu AH et al. Percutaneous flexible endoscopic necrosectomy for a retroperitoneal abscess. Endoscopy 2014: E340 - E341

[11] Yamamoto N, Isayama H, Takahara N et al. Percutaneous directendoscopic necrosectomy for walled-off pancreatic necrosis. Endoscopy 2013: E44 - E45

[12] Navarrete C, Castillo C, Caracci M et al. Wide percutaneous access to pancreatic necrosis with self-expandable stent: new application (with video). Gastrointest Endosc 2011; 73: 609

[13] van Brunschot S, van Grinsven J, Voermans RP et al. Transluminal endoscopic step-up approach versus minimally invasive surgical stepup approach in patients with infected necrotising pancreatitis (TENSION trial): design and rationale of a randomised controlled multicenter trial [ISRCTN09186711]. BMC Gastroenterol 2013; 13: 161

[14] Kumar N, Conwell DL, Thompson CC. Direct endoscopic necrosectomy versus step-up approach for walled-off pancreatic necrosis: comparison of clinical outcome and health care utilization. Pancreas 2014; 43: $1334-1339$

[15] Trikudanathan G, Attam R, Arain MA et al. Endoscopic Interventions for Necrotizing Pancreatitis. Am J Gastroenterol 2014; 109: 969-981 